\title{
СИМВОЛИЧЕСКОЕ ЗНАЧЕНИЕ 'ВОДЯНОЙ', МОТИВИРОВАННОЕ ЛАНДШАФТНЫМИ, ГИДРОЛОГИЧЕСКИМИ И БИОГЕОГРАФИЧЕСКИМИ ОСОБЕННОСТЯМИ КРАЯ
}

\section{THE SYMBOLIC MEANING 'WATER \\ SPIRIT', MOTIVATED BY LANDSCAPE, HYDROLOGICAL AND BIOGEOGRAPHIC FEATURES OF THE REGION}

\section{Yakushevich}

N. Ivashinina

Summary: The article is devoted to the analysis of sources of symbolic meaning 'water spirit' in several dialectal nominations: buchalen, sandpiper, volosatik, lopuhonya, Kamyshanov and kromeshnik. Information on the landscape and hydrological features of the locality in which dialectisms were recorded, as well as data on the ethology of some birds and worms, had a special influence on the internal form of these words.

Key words: symbolic meaning, motivation, inner form, etymological meaning.

\author{
Якушевич Ирина Викторовна \\ Д.ф.н., nрофеессор, ГАОУ ВО г. Москвы МГПУ \\ sa1107@yandex.ru \\ Ивашинина Надежда Сергеевна \\ Аспирант, ГАОУ ВО г. Москвы МГПУ \\ nadyha.92@mail.ru
}

Аннотация: Статья посвящена анализу источников символического значения 'водяной' у нескольких диалектных номинаций - бу́халень, кулик, волоса́тик, лопуху́ня, Камыша́нов и кроме́шник. На внутреннюю форму данных слов особое влияние оказала информация о ландшафтных и гидрологических особенностях местности, в которой диалектизмы зафиксированы, а также данные об этологии некоторых птиц и червей.

Ключевые слова: символическое значение, мотивированность, внутренняя форма, этимологическое значение. Аннотация: статья посвящена анализу источников символического значения 'водяной' у нескольких диалектных номинаций бу́халень, кулик, волоса́тик, лопуху́ня, Камыша́нов и кроме́шник. На внутреннюю форму данных слов особое влияние оказала информация о ландшафтных и гидрологических особенностях местности, в которой диалектизмы зафиксированы, а также данные об этологии некоторых птиц и червей.

Ключевые слова: символическое значение, мотивированность, внутренняя форма, этимологическое значение.

дяной бык), кулик, волоса́тик, лопуху́ня, Камыша́нов и кроме́шник. Выбор именно этих лексем обусловлен доминированием в их «исторической памяти» (В.Н. Телия [27]) важнейшего источника символического значения - ландшафтных, гидрологических и этологических (поведение животных) данных, которые стали «ключом» к пониманию внутренней формы этих номинаций.

В структуре лексического значения слов кромешник, Камышанов и лопухоня'водяной' относится к понятийной (ядерной) сфере. А в словах волоса́тик, кулик, бу́халень 'водяной' является результатом двойного означения и относится к ассоциативной (фоновой) сфере. Эти слова имеют прямое номинативное значение, отражающее перцептивный образ: кулик - это «небольшая болотная птица семейства ржанковых, с длинными ногами и длинным носом» [18]; бу́халень, или фразеологизм водяной бык, - птица семейства цапель, выпь [17: т. 3, с. 318; 21: с. 54]; волосатик - водяной червь [17: т. 5, с. 57]. Эти значения в свою очередь сами становится источником символизации другой, неизвестной человеку, абстрактной или фантастической реальности. В нашем случае - водяного духа [25: с. 56-83].

Внутренняя форма слова - это «осознаваемая гово- 
рящими мотивированность значения слова данного языка значением составляющих его морфем или исходным значением того же слова, т.е. образ или идея, положенные в основу номинации» [9: с. 41]. Так, лексема выпь происходит от глаголов вопить, вопль как результат чередования гласных звуков [20: т. 1, с. 369]. Производящим словом диалектного названия выпи - бу́чель - стало слово буча́mь (Курск.) 1) издавать глухой звук, гул; 2) реветь, мычать (о корове), жужжать, гудеть (о пчелах); 3) громко плакать, реветь, визжать беспрестанно [17: т. 3, с. 328]. Другая номинация выпи - бу́халень - мотивировано словом бу́хать, т.е. издавать отрывистые звуки, ухать (Влад., Тул., Вол.) [17: т. 3, с. 321]. Таким образом, в основу внутренней формы сразу нескольких номинаций выпи из ряда ее многочисленных признаков лег акустический признак птицы - ее особый крик.

По нашему мнению, традиционными источниками символического значения является 1) внутренняя форма слова; 2) отношение к обобщенному мифологическому образу (водяной) и 3) рефлексия этого образа в фольклорных и литературных произведениях. Подключение к этому списку данных этнографии, 3о0- и этологии, географии ландшафта и гидрообъектов иногда имеет решающее значение для понимания происхождения и мотивированности диалектизмов конкретного края.

Перейдем к анализу конкретных лексем.

1. Выпь, бу́халень, бу́халь, бу́чел, бу́чило, бу́ха́ла и бу́хало, водяной бык (Моск., Смол., Казан., Тобол.) [17: т. 3, с. 318, 329]. Символическое значение этих слов своеобразно - 'голос водяного'. Источником являются полевые признаки птицы. Прежде всего, этот вид семейства цапель селится на обширных водных пространствах: в труднодоступных, глухих зарослях прудов, озер, речных заливов и плавней, сильно заболоченных лугов и ивовых кустарников. Но главное то, что в живой природе ее заметить очень сложно, поскольку она активна только ночью, живет в одиночку и, если испугается, то замирает столбиком в зарослях, подняв клюв вверх и сливаясь с камышами или прикинувшись торчащей палкой. Единственное, что обнаруживает птицу, это ее крик. Звук выпи, издаваемый на лету, иногда напоминает истерический, леденящий душу женский вопль («оу» или просто «о»). Издавать столь мощный звук птице помогает пищевод, который раздувается и действует как резонатор.

В Тул. голос выпи воспринимается как крик водяного. Здесь его даже изображают в виде выпи, с зелеными ногами и длинным клювом. В народе говорили, что когда водяной кричит выпью, то это он с лешим переговаривается [6: т. 1, с. 309]. О том, что выпь - атрибут водяного, свидетельствует пословица: Выпь на его хоромах кричum [5: с. 733].
Брачная песня самца состоит из сочетания звуков, которые можно передать как «ып-прумб, ып-прумб». Предположительно, что слово выпь возникло как звукоподражание этому крику. Птица, принимает замысловатые позы, бьет клювом по воде и вбирает ее. Набрав достаточно воды, выпь резким движением запрокидывает голову назад, так что затылок касается спины, и производит глубокие, басовые звуки, похожие на рев. Затем следуют менее сильные «бу-бу», когда выпь выбрасывает оставшуюся в зобе воду. [7: т. 2, с. 475]. Именно этим звуком, похожим на мычание быка прямо под водой, и мотивировано слово бухалень. Отсюда и другое название выпи - водяной бык: это птица тикая выпь, в болоте живет, идёшь мимо болот и слышишь, будто бык ревет, выпь так кричит [4: с. 88].

Следует отметить, что из разных звуков (уханье, крик, мычание, жужжание) крик выпи более всего отождествлялся с быком. Это не случайно. У восточных славян копытное - один из зооморфных обликов водяного. Например, он может появляться в виде коровы или лошади, либо седого старца с рогами, с коровьим брюхом ногами, рогами и хвостом, весь заросший шерстью. На Русском Севере зафиксированы рассказы о неких водяных коровах, которые выходят из глубин рек, озер, из моря-океана на остров или берег. Там они «пасутся на заливных лугах, а при появлении человека снова скрываются в пучинах водоема». Н.А. Криничная считает, что миф о корове фиксирует представление древних славян о рождении мира, когда земля в виде островка суши покрывается травой, и тогда появляется чудесная корова - символ плодородия [12: с. 31, 40-42].

Итак, символическое значение 'голос водяного' у нескольких номинаций выпи мотивирован своеобразным криком птицы (особенно весной).

2. Кулик в диалектном словаре имеет несколько значений: 1) птица кулик; 2) булка в виде птицы, которую пекут в день кулика 9 марта (Курск.); ватрушка с разной начинкой (Перм., Арх.), 3) свадебный пирог (Кемер.), 4) один из ряженых на святки, лица которых закрываются маской или платком; ходить куликами - ходить по домам в святки, завязав лицо платком (Новг., Лен.) [17: т. 16, с. 65-66].

Существует несколько версий этимологии слова кулик. 1. Как звукоподражание крику кулика - «куль-куль» [23: т. 2, с. 438]: Не куличенька в болоте кули-куликает (Калуж.). [17: т. 16, с. 64]. 2. От коми-перм. куль 'чёрт, сатана, дьявол; водяной', мотивирующего святочного демона, водяного или черта, - куляша [22: с. 262]. На Крещение куляши из воды вылазят, почему и не ходят по воду, чтобы не зачерпнуть куляша [6: т. 2, с. 822]. 3. По мнению O.Н. Трубачева, слово прасл. *kul-, означавшего кривизну, сжимание, хромоту. Эти семы могли мотивировать 
святочных ряженых, демонстративно подчеркивавших в своем костюме зооморфные атрибуты куляша - горбы, рога, клюв [24: т. 13, с. 97]. Добавим, что этимологическое значение *kul- также может быть объяснено внешними признаками птицы: многие виды куликов имеют клюв, дугообразно загнутый вниз, как у серпоклюва или бегунка; либо вверх, как у шилоклювки или мородунка [7: т. 3, c. 9].

Символическое значение слова кулик амбивалентно [26]. С одной стороны, кулики (наряду с жаворонками и ласточками) приносят из вырия весну и символизируют плодородие, поскольку большинство видов этих птиц ведут дневной образ жизни и относятся к перелетным. Кулик также является символом брака, поскольку это моногамная птица. В некоторых районах (Курск. и Орл.) во время обряда встречи весны пекли булки или печенья в виде летящих куликов: Закрывай, кулик, холодную зиму: Холодная зима всем надоела. Открывай, кулик, Теплое лето [цит. по 5: с. 716].

С другой стороны, кулик являются зооморфным обликом водяного черта, демона куляша. Это обусловлено тем, что многие виды куликов ведут сумеречный или ночной образ жизни и селятся, как и выпь, в зарослях близ воды, на побережьях морей, озер и рек [7: т. 3. с. 4]. Таким образом, символическое значение'водяной'у слова кулик во многом мотивировано некоторыми внешними (загнутый клюв) и полевыми (ночной образ жизни, селится у воды) признаками этой птицы.

3. Волос, волосатик, волосень, волосач, волосец, волосиц, волосник, водяной волос, живой волос (конский волос). Так в разных районах России называли мифического червя-паразита, живущего в водоемах, внедряющегося в тело человека и приносящего страшные болезни (Волог., Калуж., Тул, Арх., Ирк., Красноярск., Смол, Новг., Свердл., Перм., Вят.) [17: т. 5, с. 57-62; т. 11, 298]. Волос как черная нитка, он прокусывает кожу и залезает в ногу // Как пиявки вот они, в тело въедаются. Потом нарывает, болит (Читин.) [2: с. 87].

Волосом называли и саму болезнь, вызванную червем. Она сопровождается образованием проломов-язв, нарывов, опухолей, гнойников, нагноением ногтей и суставов ног, рук и т.д. Одни симптомы волоса напоминают ногтоеду (ногтееду), воспаление ногтя и мягких тканей [17: т. 21, с. 267]: А волосец - это, быват, пальцы болят. Палец заболит, нарвёт и болит, и болит, и болит, и болит... (Ирк.)// Ну, от она, у ей там заболит палеи, нарывает, синеет (Ирк.). [2: с. 100, 107]. Другие - костоеда: воспаление и любое разрушение костной ткани (Калуж., Москов., Краснояр.) [17: т. 15, с. 77]: Всё, говорит, по костям, всё боль-боль шла, боль-боль шла везде, от ноги (он в ногу залез), и всё, и дошло до сердиа, и... Но а он-то так и умер от этого волосца. (Бурят.) [2: с. 106]
Самые страшные признаки волоса - симптомы рожистого воспаления - распухание и покраснение больших участков кожи на ноге, появление пузырей, которые потом превращаются в гнойные язвы: Это была такая болезнь... У ней икра ноги вот так полностью, полностью такая. Но говорили, что волос. Она, бедна, мучилася // И ломит, и с им зудит, и как мокрый делатся... И гниль даёт, и свербит. //Всё толку нету, никакого толку нету, а потом уже красна стала, ага, как опухоль, стала уже быдто (Читин.) // Осложнения от волоса сходны с флегмоной или гангреной: У молодой девочки...Палец заболел, ага. Вот она, покаместь узнали, что волос лечут, пока узнали, а ей руку отняли. Так она осталася одноручкой // Это страшная тоже болезнь, опасная. Может даже палец отнять // Он у ей был, нога, колено от тако, распухло. Она потом пошла дальше до поясу, но и она такс ей и померла. (Ирк.) // [2: с. 85-87, 98, 100, 107].

Мифического червя волосатика в некоторых областях отождествляли с водяным, например, в Вол. В Тул. им пугали детей, чтобы без разрешения не ходили на речку. А в Смол. распространено было суеверие о том, что волосатик больно кусает людей до смерти. Тамбовский и тверской волосень - это нечистый дух, который под видом костоеды может отъесть палец: Под новый год считается большим грехом прясть; у нарушителей этого обычая дух волосёнь, под видом костоеды, отъест палец. (Тамб.) [17: т. 5, с. 60]. По мнению Н.А. Криничной, волосы, как и шерсть, водяного - «знак средоточия в нем стихийной жизненной силы, физической и магичеСкой» [13: с. 326].

Однокоренные номинации мифического существа связывает праслвянский. корень ${ }^{*}$ volsъ со значением 'волос' [1: т. 8., с. 166]. Волос - имя славянского языческого бога, покровителя крупного рогатого скота, бога плодородия. Возможно, именно поэтому червь волосатик по легенде возникает из шерсти животного (лошади, коровы, реже - свиньи) или из волос человека, упавших в реку. В воде у волоса вырастает головка, и он становятся живым червяком: А он прямо вот волос небольшой, а весь... и, как у человека, мордочка-то (Читин.) [2: с. 93, 95].

Внутренняя форма слова волосатик - метафора волоса человека или шерсти животного. Реальный червьпаразит (волосатик или конский волос) также очень тонкий и длинный (до 1,5 м). Его зоологическое название - немательминт (греч. nema- 'нить' и helmins - 'червь'). Сходство с жестким конским волосом ему обеспечивает прочная оболочка-кутикула [3]. Этот червь-паразит живет в реках и озерах. Однако в отличие от мифологического персонажа, реальные волосатики человеку почти не опасны: у них нет ротового отверстия и пищеварительного тракта, поэтому питаться в теле человека они не могут и паразитируют в основном в организме насе- 
комых: кузнечиках, жужелицах, стрекозах. Есть предположение, что под видом волосатика может скрываться более опасный паразит - ришта. Этот червь, также тонкий и длинный, действительно живет в теле человека, попав в него с грязной водой перорально [3]. Однако ришта живет в тропиках и субтропиках Азии и Африки, поэтому на роль водяного-волосатика тоже не подходит.

Таким образом, волосатик как зооморфный образ водяного сходен с реальным червем-паразитом только внешне и является собирательным народным образом, персонифицирующим страшные и до сих пор мало объяснимые (как, например, рожистое воспаление или флегмона) инфекционные заболевания, сопровождаемые опасными симптомами.

4. Лопухоня - мифическое существо женского пола, живущее в водоеме: Лопухоня, в речке поселенная, болезни на всех насылает [16: т. 7, 138]. На первый взгляд, внутренняя форма диалектизма прозрачна: от слова ло́nух (лопи́х). Однако лопух в русских говорах - это собир. название всех растений с широкими листьями: весенний репейник (Калин.), калужница болотная с желтыми цветами (Брян., Олон., Ниж.), кувшинки желтые и белые (Вол., Смол., Сарат., Тамб., и др.), лопух подорожный (Астрах.), мать-и-мачеха (Смол.) и вообще всякое растение с крупными, преимущественно круглой формы листьями [17: т. 17, с. 144-145]. Этимологически восходит к прасл. корню *ор- 'лист'. Причем, по всей видимости, мотивирующими были семы 'большой' и 'широкий', т.к. данный корень стал производящим для таких слов, как лопушистый ('широколистый'), лопата, лопасть др. [24: т. 16, c. 69-73].

Мифическая лопухоня, вероятнее всего, обитает в реке Бакланка Грязовецкого района Вол. Как у многих других небольших рек этого региона, у Бакланки медленное течение и болотистые берега [10: с. 110-111]. Множество заводей с почти стоячей водой густо поросли лопухо́й - кувшинками и кубышками: Улопухи - cветлый лист, а отдельно головки, иветут самоварчиком; ой самоварчик у лопухи надо сорвать. Все лопухой покрывается, не видно реку [16: т. 7, с. 137]. Следовательно, лопухоня - Вологодская водяница, живущая в реке среди кувшинок.

5. Камышанов - водяной Соль-Илейкого района Оренб.: Станешь из речки воду брать, а камышанов тебе и схватит за руку [16: т. 13, с. 33]. Производное слово - камыш. Выбор народным сознанием значения именного этого слова в качестве мотивирующего обусловлено особенностью гидрографии Соль-Илецкого района: именно здесь имеется много пересыхающих мелководных озер, заросших камышами. Особенно знаменит узел слияния рек Илек и Урал - огромное пространство реч- ной долины шириной до 12 км, густо поросшее камышовыми зарослями. Более 80-90\% стока рек Урал и Илек приходится на короткий период весеннего половодья, а в остальное время так мало воды, что камыши заросли заполняют не только все пространство поймы, но и русло [15: с. 46-49]. Таким образом, именно номинация камыша, а не воды и водоема (типа водяной, речной и пр.) мотивировало лексему Камышанов. Этого мифологического персонажа трудно назвать водяным, ровно как и лешим. При полном отсутствии в Соль-Илецком районе лесов Камышанов совмещает «обязанности» и того и другого. Слово зафиксировано в 1955 г., и, к сожалению, Камышанов вряд ли «дожил» до наших дней, т.к. поймы рек были в основном распаханы в период освоения Целины. В прошлое ушли и камыши, и их хозяин, и называющее его слово.

6. Кромешник - 1) общее название водяных, леших, домовых и т. п. Снимутся кромешники в карты резаться, так наш все просадит - и воду, и рыбу, а под конец и сам себя [17: т. 15, с. 275]. Слово кромешник зафиксировано в Кадуйском районе Вол. По нашему мнению, оно называет водяного-картежника, который фигурирует в известных легендах об озерах Кадуйского и Вытегорского районов. Так, о куштозерском водяном известно, что он всякий раз проигрывал в кости могучему хозяину озера Онего сначала рыбу, потом воду, а затем и себя самого: уходил к царю отрабатывать проигрыш в Онего, а потом снова возвращался» [14: с. 74].

Внутренняя форма слова кромешник мотивирована однокренным кромешый - 'ад, преисподняя': Провались-ко ты в кромешный (Вят., Костром.) [17: т. 15, с. 275]. В древнерусском языке это слово было известно повсеместно в составе фразеологизма тьма кромешная, а также в значении 'чужой, иноземный' [19: т. 8, с. 71]. Таковыми для простых людей были, например, опричники или нечистая сила. Однако как имя водяного кромешник зафиксировано только в Кадуйском районе Вол.

Этому есть причина. Именно в этих районах Вол., расположена возвышенность Мегрская гряда. В пределах этой гряды насчитывается несколько десятков периодически исчезающих карстовых озер. В маловодные годы вода из этих озер может полностью уйти под землю в карстовые пещеры через воронки-поноры, напоминающие вход в преисподнюю. Среди этих озер особенно выделяется крупное Куштозеро, в котором, по легенде и обитает, водяной-картежник. Карст - общее название процессов растворения и отчасти механического размыва горных пород природными водами, а также возникающих при этом форм рельефа -подземных полостей, по которым текут грунтовые воды. В ряде случаев эти полости сообщаются с поверхностью земли, и озерная вода может в них «исчезать» иногда полностью обнажая 
дно водоема в маловодные годы. Водяной-кромешник в данном случае является персонификацией ушедшей воды и «знатоком» преисподней, по путям которой он то «уходит», то «возвращается». Косвенным подтверждением того, что кромешник - это водяной-игрок карстовых озер является переносное значение слова - 'жадный, корыстный человек' (Вол.) [16: т. 6, с. 170], к коим можно причислить и картежника.

Подведем итог. Анализ символического значения диалектных слов - одна из важнейших задач лингвокультурологии и лингвопсихолингвистики. К источникам символического значения следует отнеси данные этнографии, этологии, географии ландшафта и гидрообъектов. Их роль в раскрытии внутренней формы диалектизмов, возникших в определенных районах России, иногда имеет решающее значение. Уникальность отобранных для исследования слов заключается в том, что в их внутренней форме особенно отчетливо «звучит» голос природы той местности, где эти слова были зафиксированы. А значит, национально-культурная и когнитивная составляющая слова - чувство Родины - материализуется в образах конкретного животного, ландшафта или водоема России.

\section{СОКРАШЕНИЯ}

Обл. - область. Губ. - губерния.

Арх. - Архангельская обл. губ.
Астрах. - Астраханская обл., губ.

Брян. - Брянская обл.

Бурят. - Бурятская АССР

Вол. - Вологодская обл., губ.

Вят. - Вятская губ.

Ирк. - Иркутская обл. губ.

Калин. - Калининская обл.

Калуж. - Калужская обл., губ.

Костр. - Костромская обл., губ.

Краснояр. - Красноярский край

Курск. - Курская обл., губ.

Лен. - Ленинградская обл.

Моск. - Московская обл., губ.

Ниж. - Нижегородская обл., губ.

Новг. - Новгородская обл., губ.

Олон. - Олонецкая губ.

Оренб. - Оренбургская обл., губ.

Орл. - Орловская обл., губ.

Перм. - Пермская обл., губ.

Сарат. - Саратовская обл., губ.

Свердл. - Свердловская обл.

Смол. - Смоленская обл., губ.

Тамб. - Тамбовская. обл., губ.

Тул. - Тульская обл., губ.

Читин. - Читинская обл.

\section{ЛИТЕРАТУРА}

1. Аникин А.Е. Русский этимологический словарь. Вып. 8. - М.: Ин-т русского языка им. В.В. Виноградова РАН: Ин-т Сибирского отделения РАН, 2014. - 352 с.

2. Афанасьева-Медвелева Г.В. Словарь говоров русских старожилов Байкальской Сибири / ред. В.М. Гацак, С.А. Мызников. - Иркурск, 211. Т. 8. - 536 с.

3. Большая российская энциклопедия. URL: https://bigenc.ru. (дата обращения: 27.01.2020).

4. Войтенко А.Ф. Словарь говоров Подмосковья. Вып. 1. - М., 1995. - 216 с.

5. Гура А.В. Символика животных в славянской народной традиции. - М.: Индрик, 1997. - 912 с.

6. Даль В.И. Толковый словарь живого великорусского языка: в 4-х т. - М.: ТЕРРА, 1994.

7. Дементьев Г.П., Мекленбурцев Р.Н., Судиловская А.М., Спангенберг Е.П. Птицы Советского Союза. - М.: Советская наука, 1951. Т. 2. - 480 с. Т. 3 - 680 с.

8. Жбанков М.Р. Миф // Новейший философский словарь. - 3-е изд., исправл. - Минск: Книжный Дом, 2003. - 1280 с.

9. Зализняк А.А. Многозначность в языке и способы ее представления. Диссертация на соискание ученой степени доктора филологических наук. - М., 2002. -461 c.

10. Карандеева М.В. Геоморфология Европейской части СССР. - М.: Изд-во Московского университета, 1957. - 315 с.

11. Красных В.В. Этнопсихолингвистика и лингвокультурология как конституенты новой научной парадигмы // Сфера языка и прагматика речевого общения. Международ. сб. науч. трудов. Книга 1. - Краснодар, 2002. С. 204-214.

12. Криничная Н.А. Мифология воды и водоемов. Былички, бывальщины, поверья, космогонические и этимологические рассказы Русского Севера: исследования. Тексты. Комментарии. - Петрозаводск: Карельский научный центр РАН, 2014. - 390 с.

13. Криничная Н.А. Русская мифология: Мир образов фольклора. - М.: Академический проект; Гаудеамус, 2004. - 1008 с.

14. Максимов С.В. Легенды и мифы России. - Ростов на Дону: Феникс; СПб.: Северо-Запад, 2006. - 416 с.

15. Ресурсы поверхностных вод СССР. Т. 12. Нижнее Поволжье и Западный Казахстан. Вып. 2. - Л.: ГМИ. - 512с.

16. Словарь говоров русского севера. Т. 1-7. - Екатеринбург: Издательство Уральского университета, 2001-2018.

17. Словарь русских народных говоров / под ред. Ф.П. Филина. - М.-Л., 1965-2016.

18. Словарь русского языка / под ред. А.П. Евгеньевой. 4-е изд. В 4-х тт. M., 1999. URL: http://feb-web.ru/feb/mas/mas-abc/default.asp (дата обращения: 


\subsubsection{0).}

19. Словарь русского языка XI-XVII вв. Вып. 8. - М.: Наука, 1981. - 352 с.

20. Фасмер М. Этимологический словарь русского языка / пер. с нем. и доп. 0.Н. Трубачёва. - М.: Прогресс, 1964-1973. Т. 2. - 672 с.

21. Федоров А.И. Фразеологический словарь русского языка. - М., Астрель, АСТ, 2008. - 879 с.

22. Черепанова 0.А. Мифологическая лексика русского языка. Диссертация доктора филологических наук. - М.: РГБ, 2007. - 434 с.

23. Шанский Н.М. Этимологический словарь русского языка. В 2-х тт. - М., 1963-2007.

24. Этимологический словарь славянских языков: праславянский лексический фонд / под ред. О.Н. Трубачев. М.: Наука, 1974-2014. Вып. 1-39.

25. Якушевич И.В. Символ «дом» в русском языке и поэтическом тексте - Владимир: Транзит-ИКС, 2018. - 182 с.

26. Якушевич И.В. Энантиосемия в лексико-семантической структуре символа // Вестник ИГлу. 2012. № 2 (19). - Иркутск. С. $72-77$.

27. Телия В.Н. Русская фразеология. Семантический, прагматический и лингвокультурологический аспекты. - М.: Школа «яЗыки русской культуры», 1996. С. 226

28. Бердяев Н.А. Истоки и смысл русского коммунизма. - М.: Наука, 1990. С. 96

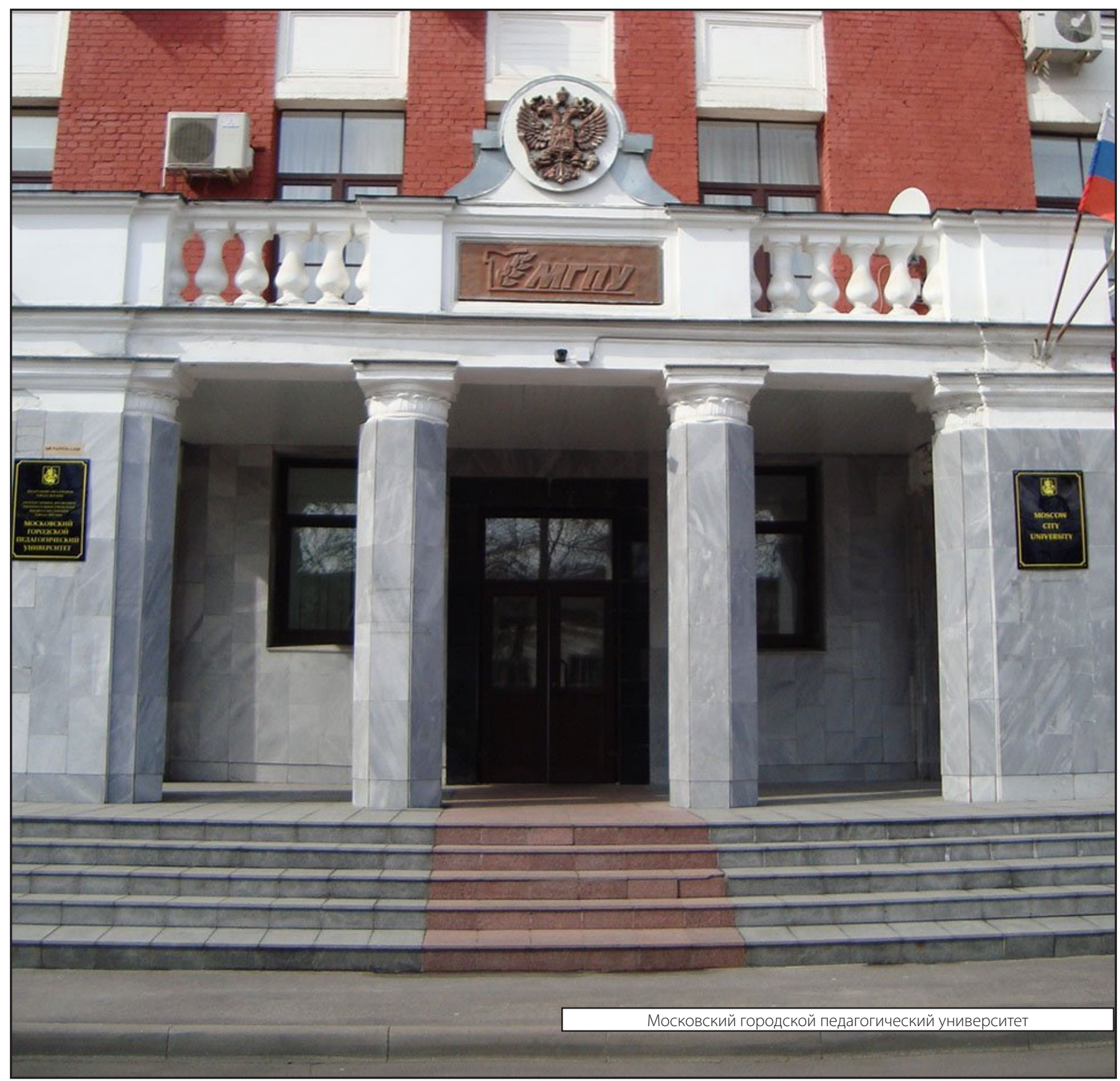

